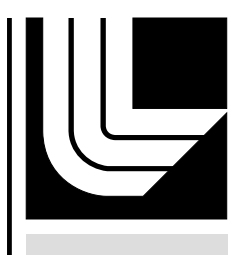

LAWRENCE LIVERMORE N A TION A L LABORATORY

Literature Review on the Effects of Prescription Fire on theEcology of Site 300

R. Preston

March 14, 2011 
This document was prepared as an account of work sponsored by an agency of the United States government. Neither the United States government nor Lawrence Livermore National Security, LLC, nor any of their employees makes any warranty, expressed or implied, or assumes any legal liability or responsibility for the accuracy, completeness, or usefulness of any information, apparatus, product, or process disclosed, or represents that its use would not infringe privately owned rights. Reference herein to any specific commercial product, process, or service by trade name, trademark, manufacturer, or otherwise does not necessarily constitute or imply its endorsement, recommendation, or favoring by the United States government or Lawrence Livermore National Security, LLC. The views and opinions of authors expressed herein do not necessarily state or reflect those of the United States government or Lawrence Livermore National Security, LLC, and shall not be used for advertising or product endorsement purposes.

This work performed under the auspices of the U.S. Department of Energy by Lawrence Livermore National Laboratory under Contract DE-AC52-07NA27344. 


\title{
LITERATURE REVIEW OF THE EFFECTS OF Prescription Fire on the ECOlOgy OF SITE 300
}

\author{
PREPARED FOR: \\ Lawrence Livermore National Laboratory \\ P.O. Box 808 \\ 7000 East Avenue \\ Livermore, CA 94551 \\ Contact: James Woollett
}
PREPARED BY:
ICF International
630 K Street, Suite 400
Sacramento, CA 95814
Contact: Robert Preston
916.737.3000

September 2010

INTERNATIONAL 
ICF International. 2010. Literature Review on the Effects of Prescription Fire on the Ecology of Site 300. September. (ICF 00563.10.) Sacramento, CA. Prepared for Lawrence Livermore National Laboratory, Livermore, CA. 


\section{Contents}

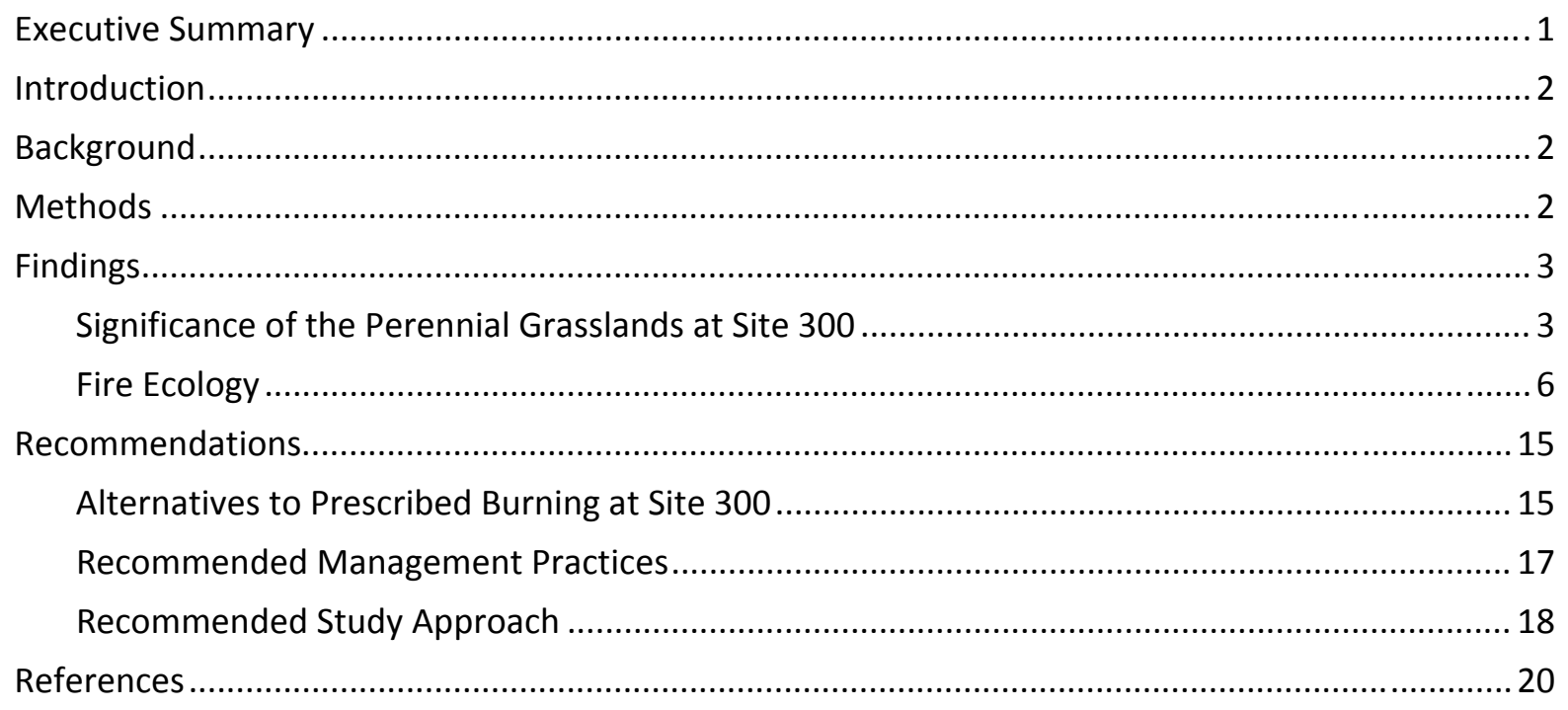




\section{Literature Review on the Effects of Prescription Fire on the Ecology of Site $\mathbf{3 0 0}$}

\section{Executive Summary}

This report presents the results of a review of scientific literature review conducted by ICF International (ICF) to collect basic information on California native perennial grasslands in California, the influence of fire on these grasslands, and management tools for restoring and maintaining them. The objective of the review was to summarize the current state of knowledge pertaining to the possible effects-both beneficial and detrimental-of prescribed fire on the ecology of Site 300.

Native perennial grasslands at Site 300, which are among the largest concentrations of native grasslands in California, have been characterized as unique because the dominant grass is pine bluegrass (Poa secunda). Native grasslands at Site 300 are correlated with areas subject to prescribed burns, suggesting that the extent and composition of the native grasslands have been influenced by repeated burning. The size and locations of prescription burns might change in coming years; accordingly, this report examines how such changes might affect listed biota, including special-status plants, and the notable ecological conditions present at Site 300.

Little information is available on the ecology of pine bluegrass grasslands, as most of the research on native California perennial grasslands has focused on purple needlegrass (Nassella pulchra). Although fire was historically a natural part of the ecology of California grasslands, the role that fire currently plays is difficult to elucidate. Fire can have positive, negative, or neutral effects on native grasslands, depending on the frequency and timing of the burns and the response of individual species to fire. In general, the observed positive effects on native species have been limited and of short duration, mostly on sites that are ungrazed and subject to repeated burns. At Site 300, the response of native grasslands to reducing the number and frequency of prescribed burns is difficult to predict; however, the most likely responses are either minimal change in the amount and composition of the native grasslands or a reduction of the extent of native grasslands, presumably to the level present prior to the start of prescription burning.

Recommended management practices for native grasslands at Site 300 are listed below.

- Monitor species composition, distribution, and cover; detect changes; and identify the factors responsible for those changes.

- Inventory and map invasive species.

- Rehabilitate fire trails.

- Collect experimental data on the effects of fire on pine bluegrass.

- Use integrated management tools to maintain, restore, and rehabilitate grasslands and other areas at Site 300.

A recommended approach for further study is presented for establishing a quantitative record of existing ecological conditions and for collecting data to determine changes from existing conditions. 


\section{Introduction}

To comply with the requirements of the Endangered Species Act (ESA) of 1973, as amended, the Lawrence Livermore National Security, LLC (acting on behalf of the National Nuclear Security Administration/U.S. Department of Energy) at Lawrence Livermore National Laboratory (LLNL) is collecting updated biological assessment information regarding the ecological impacts of fire use at the Site 300 Experimental Test Site. LLNL has historically conducted prescription burns across approximately 2,000 acres of Site 300 on an annual basis to safeguard test facilities and operations from the risk of wildfire encroachment. Prescription burns began in 1960, and although fire frequency varies among the designated burn areas, all have been burned at least once (Sharry 2010). A patchwork of native perennial grassland communities and associated special-status plant and animal populations occur onsite in many areas that have been receiving these treatments. Because the size and locations of prescription burns may shift in coming years, an evaluation is warranted to determine how these shifts may affect listed biota, including rare plants, and the distinct ecological conditions present on the site.

This report presents the results of a literature review conducted by ICF International (ICF) to collect basic information on native perennial grasslands in California, the influence of fire on these grasslands, and management tools for restoring and maintaining them. The objective of this study was to review the scientific literature on California native grasslands and summarize the current state of knowledge pertaining to the possible effects—both beneficial and detrimental—of prescribed fire on the ecology of Site 300. The results of this review are intended to inform future management practices that may be carried out at Site 300 to maintain the plant and wildlife communities and to ensure that the ecological conditions benefit the special-status species that inhabit the Site. This review is also intended to identify a study approach to investigate changes over the next 10 years in the burned areas and in areas where burning will be discontinued. ICF senior botanist and plant ecologist Robert Preston, Ph.D., conducted the literature review and authored the report with editorial assistance from Larry Goral.

\section{Background}

Native grasslands at Site 300 have been characterized as a unique resource (BioSystems 1986). Approximately 447 acres of grassland dominated by native perennial grasses are present at Site 300, placing it among the largest known concentrations of native grassland in California (Barry 1972). The dominant native grass at the site is pine bluegrass (Poa secunda), also known as onesided bluegrass and Sandberg bluegrass. In contrast, most other large areas of native grassland in California are dominated by purple needlegrass (Nassella pulchra) or other native perennial grasses. This review attempts to determine if the native grassland at Site 300 is truly unique, to assess the role of fire in the ecology of native perennial grasslands, and to evaluate how much of the information obtained from the study of other perennial grassland types is applicable to the grasslands at Site 300.

\section{Methods}

To identify relevant published literature, Dr. Preston relied primarily on Google Scholar (http://scholar.google.com/) and MELVYL (http://ucdavis.worldcat.org/). The searches used 
combinations or variations of the following keywords and phrases: California, native, grassland, fire, prescribed burning, Poa secunda, pine bluegrass, wildlife, and mammals. Additional references were identified from citations in the papers obtained through the searches and by doing a citation search for papers that contained relevant information. Additional information was obtained from ICF project files and from technical documents prepared by LLNL staff and by other consultants for LLNL.

\section{Findings}

There is a large body of literature on California native perennial grasslands; however, much of the literature has a rather narrow perspective, focusing on the restoration and management of grasslands dominated by purple needlegrass. To the extent possible, the findings presented here focus on the effects of fire on the type of perennial grasslands found at Site 300. Because most of the literature addresses research on purple needlegrass, and because responses to fire are likely species specific, the application of this information to the native grasslands at Site 300 is speculative, and the recommended management practices are necessarily experimental.

The Findings discussion considers the significance of perennial grasslands and other habitats at Site 300 , then addresses fire ecology as it pertains to native perennial grasslands and the conditions at Site 300. Recommendations presents a suite of alternatives to prescribed burning, a set of recommended management practices, and a study approach for monitoring perennial grasslands at Site 300 to detect changes that may occur following the end of prescribed burning.

\section{Significance of the Perennial Grasslands at Site $\mathbf{3 0 0}$}

Within the California Floristic Province (Hickman 1993), large areas of grassland dominated by native perennial grasses appear to be very rare. Barry (1972) compiled a list of known occurrences of native grasslands, of which only 10 sites exceeded 50 acres. The 447 -acre extent of the native perennial grasslands at Site 300 places it among the largest occurrences of native perennial grassland in the state.

BioSystem's (1986) report on the vegetation of Site 300 stated that the pine bluegrass-dominated plant community constitutes a unique resource. Because pine bluegrass is common throughout California and the western United States and occurs in many different habitats, determining the veracity of this characterization becomes a nuanced challenge. The discussion is necessarily multifaceted, involving three areas of examination: the ecology, distribution, and taxonomy of pine bluegrass; the ecological community's traditional views of native perennial grassland in California; and the unusual circumstances present at Site 300.

Pine bluegrass is widespread in western North America, with disjunct populations in Quebec and Chile (Kellogg 1985a, 1985b). The species' occurrence across a wide range of habitats in concert with minor morphological differences has led to the recognition of many separate taxa, all of which are currently included as minor forms of a single highly variable species-Poa secunda (Kellogg 1985a, 1985b). Despite the lack of morphology-based taxonomic resolution, it has possible that California populations in the interior Coast Ranges may represent a distinct ecotype; this tentative conclusion is supported by the occurrence of populations in habitats that range from desert to alpine peaks, include dry to mesic sites, and have soils derived from various substrates (including serpentine). 
Native grasslands dominated by pine bluegrass are not unique to Site 300. Holland (1986) recognized pine bluegrass grassland as one of five native California grassland communities on the basis of his observations on the Elkhorn Plain in San Luis Obispo County and along Monocline Ridge in Fresno County, and on Dean Taylor's observations at Site 300 (i.e., BioSystems 1986). Holland (1986) described the distribution of pine bluegrass grassland as lower elevations in the inner South Coast Ranges from Contra Costa County south to eastern San Luis Obispo County. Grasslands dominated by pine bluegrass have been reported at the Carrizo Plains National Monument (Kimball and Schiffman 2003), and small stands of pine bluegrass grassland are found on north-facing slopes throughout the Diablo Range, in the Temblor Range, and in the Tehachapi Mountains (R. Preston pers. obs.). Moreover, pine bluegrass grassland is not restricted to the central California Coast Ranges. Sawyer et al. (2009), who renamed this community the Poa secunda Herbaceous Alliance, updated the regional distribution to include other bioregions, including the Sierra Nevada and Great Basin.

Although grasslands dominated by pine bluegrass have been studied in the Palouse Prairie of Washington and in other western states, very little documentation of pine bluegrass grassland appears to be available for the central California Coast Ranges, other than the BioSystems (1986) report. It is unclear, therefore, whether this plant community is actually rare in that bioregion or is merely underdocumented. The California Natural Diversity Database (CNDDB) (2010) does not list any occurrence records for pine bluegrass grassland, and the discussion for the Poa secunda Herbacous Alliance in Sawyer et al. (2009) suggests that most of the available data come from the Sierra Nevada and Great Basin bioregions. Much of the central California Coast Ranges where pine bluegrass grassland occurs is under private ownership and not readily accessible; this lack of accessibility may contribute to the dearth of information from this region. Regardless of the reason, pine bluegrass grasslands are sufficiently uncommon that the CNDDB regards them as a natural community that warrants monitoring (California Department of Fish and Game 2007; California Natural Diversity Database 2010). Pine bluegrass grassland has a state rarity ranking of G5S3 (G5 is globally secure; S3 is vulnerable in California due to a restricted range, relatively few stands, recent and widespread declines, or other factors making it vulnerable to extirpation) (California Natural Diversity Database 2010).

Another reason for the lack of information on pine bluegrass grassland is that the preponderance of research on native California grasslands has focused on purple needlegrass. The reason for this focus stems from the promotion of the concept of the California prairie (Clements 1920, 1934; Clements and Shelford 1939) as a pristine, pre-European plant community dominated by native perennial grasses-in particular, purple needlegrass. The central tenets of this concept are listed below.

- Prior to the settlement of Europeans on the west coast of North America, grasslands were widespread in California's Central Valley and adjacent foothills.

- These grasslands were dominated by perennial bunchgrasses, the most common and abundant of which was purple needlegrass.

- Nonnative annual grasses and forbs became established following the founding of Spanish settlements on the west coast of North America in the seventeenth century.

- Nonnative annual grasses replaced the native perennial grasses as a result of grazing and other disturbances. 
- Current stands of native perennial grasses are remnants of this formerly more widespread plant community.

The paradigm of a pristine California prairie dominated by purple needlegrass has been widely accepted (e.g., Munz and Keck 1949; Burcham 1957; Barry 1972; Heady 1977; Bartolome et al. 2007), and it continues to shape perceptions about the original vegetation of California and to guide the direction of research on the ecology and restoration of native perennial grasslands in California. Because pine bluegrass and other perennial species have been regarded as only minor components of California native grasslands, little research has been done on these types in California (Hamilton 1997) beyond that directed at purple needlegrass grasslands. The primary focus on purple needlegrass and lack of studies on other native grasses may even have led to a perception that grassland types other than purple needlegrass grasslands have been largely eliminated (e.g., Baker 1989; Murphy and Erlich 1989). The assessment that perennial grasslands at Site 300 are unusual because they are dominated by pine bluegrass may be a misconception fueled by the paradigm of the pristine California prairie.

An alternative point of view, proposed by Jepson (1925), was that the original vegetation of California's Central Valley was not prairie but consisted of vast areas dominated by native annuals interspersed with alkaline flats (characterized by alkali-tolerant species) and vernal pools. Perennial grasslands, where present, occurred primarily in more mesic habitats such as coastal prairies and in the foothills adjacent to the Central Valley, but they were found only at scattered locations in the Central Valley. Although support for the latter point of view has been slow to develop, it is gaining wider acceptance (Biswell 1956; Twisselmann 1967; Wester 1981; Hamilton 1997; Holstein 2001; Schiffman 2007; Minnich 2008). Bartolome and Gemmill (1981) suggested that purple needlegrass is favored by disturbance and that, like nonnative annual grasses, may now be common as a result of widespread disturbance. In addition, grassland communities dominated by species other than purple needlegrass may also have been present, such as those dominated by creeping wildrye (Leymus triticoides) (Holstein 2001). Barry (1972) noted that one of the largest areas of native perennial grassland in the Central Valley was dominated by alkali sacaton (Sporobolus airoides).

Based on an analysis of floristic lists from relict grassland areas throughout California, Schiffman (2007) suggested that vegetation of Site 300 was once characterized by a high proportion of annual forbs and relatively few perennial grasses. Surveys conducted in the interior South Coast Ranges from Alameda County to Kern County found that pine bluegrass stands were regularly observed on north-facing slopes (R. Preston pers. obs.), suggesting that the original vegetation of Site 300 was a mosaic of areas where native annuals predominated, interspersed with stands of native perennial grasses. Whether the vegetation at Site 300 was originally mostly native annuals or a mosaic of native annuals and native perennial grassland, no evidence suggests that it was originally a bunchgrass prairie dominated by purple needlegrass. The BioSystems (1986) report suggested that one of the principal values of pine bluegrass grassland at Site 300 is that it is the first documented example of an alternative to the California prairie paradigm.

Thus, the native perennial grasslands at Site 300 are significant for multiple reasons. Site 300 supports the largest known area of native grasslands in California dominated by pine bluegrass. Grasslands at Site 300 also appear unique in being on publicly owned lands, with active management and monitoring; the limited access to Site 300 makes it a de facto habitat preserve. In addition to preserving the largest area of pine bluegrass grassland in California, Site 300 may also be preserving an endemic ecotype of pine bluegrass. The grasslands at Site 300 are potentially a valuable source of information on the ecology of the original California grasslands because 
dominance by pine bluegrass, coupled with high diversity of native annual and perennial forbs, provides an alternative model to the prevailing model that native perennial grasslands in California were historically dominated by purple needlegrass and other grasses.

The loss or decline of native perennial grasslands at Site 300 would have several adverse consequences. The loss of these grasslands would constitute a substantial reduction in the amount of a rare natural habitat. Other special-status plants, including those at Site 300, are known to be associated with Poa secunda, and loss of pine bluegrass grassland might be accompanied by loss of special-status species. The loss of these grasslands would also create a missed opportunity to study the ecology of an ecosystem that may be more similar to the original California grasslands than the current model (i.e., that based on the California prairie paradigm). If native perennial grasslands are to be managed and preserved in other areas, a basic knowledge of their ecology and composition is essential.

\section{Fire Ecology}

\section{Overview of the Ecological Systems in the Burned and Unburned Areas}

Site 300 occupies approximately 7,000 acres in the eastern foothills of the Diablo Range, straddling the border between Alameda and San Joaquin Counties. Natural communities at the site were mapped and classified by BioSystems (1986) and Jones \& Stokes (2002). Most of the vegetation (about 5,533 acres) is annual grassland dominated by introduced grasses (Avena, Bromus sp.). Perennial grasslands are scattered around the site but are most abundant in the northern half, where they appear to be associated with areas subject to annual prescribed burning. The perennial grassland is dominated by native perennial grasses (Poa secunda, Nassella pulchra).

Other plant communities at Site 300 are not subject to annual burning. A small amount of oak woodland is present in the southern canyons of the site, mostly on north-facing slopes. The oak woodland consists of scattered blue oak (Quercus douglasii) and valley oak (Q. lobata) with an understory of annual grassland. Coastal scrub, present on steep, rocky slopes in the southwestern portion of the site, is dominated by soft chaparral scrubs, including California sage (Artemisia californica), California buckwheat (Eriogonum fasciculatum), black sage (Salvia mellifera), and California matchweed (Gutierrezia californica). Other less common vegetation types include wetlands associated with seeps and springs along the intermittent streams that drain the site, vernal pools, and small stands of riparian scrub.

The BioSystems (1986) report noted the geographic correlation between native perennial grassland and areas subject to prescribed burns and suggested that burning was responsible for the extent of native grasslands at Site 300. The report recommended that prescribed burning be continued at Site 300 and expanded into additional areas.

\section{Effects of Fire}

\section{Soil Health and Erosion}

Fire can have multiple potential effects on the soil. Direct effects can include reduced surface and soil organic matter, decreased available nitrogen and other essential elements, altered physical properties, and decreases in soil microbes and soil-dwelling invertebrates. Indirect effects can include increased potential for erosion (Neary et al. 1999). However, fires in grasslands are fast 
moving, have little available fuel, and do not transfer as much heat to the soil as do slower fires in heavier fuels (Bennett et al. 2002; Snyman 2003); consequently, fire generally has minimal effects on soils in grasslands (Vogl 1979, Neary et al. 1999, Allen 2006). Fire temperatures during grassland fires are low enough to allow the survival of most seeds, especially seeds of annuals (Gonzalez and Ghermandi 2008), as well as soil bacteria and fungi (Picone et al. 2003). The main adverse effectthe loss of plant litter-can result in soil compaction, higher soil temperatures, and lower soil water content (Bennett et al. 2002, Snyman 2002, 2003), conditions that can in turn reduce plant growth rates.

In contrast with single fire events, frequent fires may result in the gradual loss of carbon, calcium, magnesium, and potassium and may result in the development of clay crusts that are less water permeable than the original soils, leading to increased runoff and more potential for erosion (Mills and Fey 2004). In addition, frequent fires may result in the gradual loss of nitrogen and soil microbes, leading to lower plant production rates (Ojima et al. 1994; Snyman 2002, 2003).

\section{Species Composition, Distribution, and Diversity}

\section{Vegetation}

Many papers have noted that fire was historically a natural part of the ecology of California grasslands, although the role that fire plays is difficult to elucidate (e.g., Heady 1977; Dyer et al. 1996). Because California grasslands evolved with fire as a natural part of the ecosystem, fire should have little effect on grasslands, while other factors, such as grazing or disturbance, should have greater effects (Heady 1972; Vogl 1979; Bartolome et al. 2004). Moreover, it may be very difficult to demonstrate that fire has either a positive or negative effect on grassland species composition and diversity, because nonnative grassland species are also adapted to fire (D'Antonio et al. 2002).

D'Antonio et al. (2002) cited many potential effects that could result from burning, including changes in light availability, temperature, moisture regime, available nutrients, and germination release, and suggested that these effects could confer an advantage for native perennial grasses. However, studies testing the effects of prescribed burning on native grasses-focused primarily on purple needlegrass and coastal prairie-have had equivocal results. Most studies have found that burns do not favor an increase in the cover or abundance of native perennial grasses (Hatch et al. 1991; Dyer et al. 1996; Hatch et al. 1999; Klinger and Messer 2001; Seabloom et al. 2003a; Bartolome et al. 2004; Marty et al. 2005). Studies that have found positive fire effects, such as increases in species richness, also found that this effect was limited to specific soil types (Harrison et al. 2003).

Some studies have found a decrease in annual grasses and an increase in native and nonnative forbs after burns (Hervey 1949; Parsons and Stohlgren 1989; Pollak and Kan 1998; Klinger and Messer 2001), possibly due to a decrease in the number of grass seeds on or near the soil surface (Moyes et al. 2005). Other studies have found that the cover and diversity of native grasses and annual forbs increased after consecutive years of burning, possibly because of thatch removal associated with burning (DiTomaso et al. 1999). A benefit from burning may occur in cases where native perennials are already at high levels (Harrison et al. 2003). Dyer $(2002,2003)$ found that purple needlegrass plants were larger and produced larger seeds after burns, suggesting that burns had a positive effect on reproduction through higher germination rates and more reliable seedling establishment.

In general, however, the observed positive effects on native species have been limited and of short duration, mostly on sites that are ungrazed and subject to repeated burns (D'Antonio et al. 2002). 
Other environmental factors often have stronger effects that can confound the effects of burning. These include soil type (Harrison et al. 2003); slope aspect (Dyer et al. 1996; Hatch et al. 1999); and annual variation in weather (Hatch et al. 1991; Dyer et al. 1996; Marty et al. 2005).

Most papers examining fire ecology in California grasslands have focused on range improvement or restoration, and few have looked at the fire ecology of species other than purple needlegrass. Schlising et al. (1996) found that lowland shooting star (Dodecatheon clevelandii), a common perennial forb that occurs in grasslands, did not appear to benefit from a burn in the preceding year. Gillespie and Allen (2004) found mixed effects of burning for round-leaved filaree (California macrophyllum), with lower seedling establishment in burned plots but higher seed production by plants in burned plots. Seed predation in large-flowered fiddleneck (Amsinckia grandiflora) is generally high, but in years with lower levels of granivory, burning appears to facilitate seed predation (Espeland et al. 2005).

\section{Wildlife}

Fire has many potential effects-both adverse and beneficial—on wildlife in grassland communities. Potential adverse effects include direct mortality resulting from burns, heat stress, asphyxiation, or physiological stress, as well as indirect effects such as changes in the quality of quantity of foraging or nesting sites, predation pressure, incidence of parasitism and disease, intensity of competitive interactions, and patterns of social interactions (Kaufman et al. 1990). Despite these potential effects, relatively little evidence of wildlife mortality from grassland fires has been reported. Many animals, including small rodents, can escape fires by remaining in burrows, moving to adjacent unburned areas, or seeking refuge in bare patches of soil, such as gopher mounds (Geluso et al. 1986). Nests and young of ground-nesting birds and small mammals with aboveground nests are vulnerable to fire (Erwin and Stasiak 1979). Because grassland fires are fast moving and have relatively little available fuel, soil temperatures are not elevated more than a few centimeters below the surface (Bennett et al. 2002; Snyman 2003); consequently, burrows provide a safe zone for small mammals and reptiles, as well as amphibians and other animals that utilize mammal burrows.

Most of the available information on effects of wildlife in grasslands comes from studies of small mammals in tallgrass prairies of midwestern North America. These studies found that some small mammal species differentially use burned and unburned areas of grassland (Cook 1959; Beck and Vogel 1972; Bock and Bock 1978; Crowner and Barrett 1979; Schramm and Willcutts 1983;

Kaufman et al. 1983, 1988, 1989; Clark and Kaufman 1990; Hoagstrom et al. 1992). Species that tend to prefer burned areas include seed-eating birds and rodents, because fire removes the vegetation litter, making the seeds more apparent (Bock and Bock 1978; Reed et al. 2004, 2005). Species that prefer the presence of grass litter for cover or nesting tend to avoid burned areas. Early summer burns create a shortage of cover for small wildlife species (Vogl 1979), but fall burns may have less of an effect on cover and wildlife preference because they occur shortly before the beginning of the growing season and the vegetation recovers more quickly (Chance 1986).

An attempt was made to determine the effects of prescribed burns at Site 300 on small mammals by sampling before and after burns (Jones \& Stokes 2003). Sample sizes were too small to support specific conclusions, but no mortality was observed, and deer mice were captured in the burn area following the burn.

Little information is available on the potential effects of grassland fires on amphibians, but the effects are likely to be species- and life stage-specific (Pilliod et al. 2003). The most likely effects at Site 300 would be that burned areas might create adverse conditions for the dispersal of individuals 
across the area, as burned areas would have less vegetation cover and would be blackened, leading to greater levels of solar radiation and higher soil temperatures.

\section{Invertebrates}

Very little is known about the effect of grassland fires on invertebrate populations. Prescribed burning in grasslands does not appear to adversely affect the diversity or abundance of flying insects (Panzer and Schwartz 2000). On the other hand, ground-dwelling insects such as ants may decline with frequent burning (Reed et al. 2004). This could have an adverse effect on the flora and fauna, as ants are food for some wildlife species, such as coast horned lizard, and ants harvest seeds of grassland species, a behavior that may be important for the dispersal of some plants.

\section{Effects of Fire at Site 300}

\section{Special-Status Plants}

Eight special-status plant species have been identified at Site 300 (Jones \& Stokes 2002). All these species inhabit grasslands, although the microhabitat requirements differ among the species. Very little species-specific information is available on these species' response to fire, and most of the available information comes from studies conducted at Site 300. General effects of fire on grasslands are likely to apply to these species, although species-specific responses to fire make it difficult to more than generalize about how fire would affect them.

Burn treatments on experimental large-flowered fiddleneck (Amsinckia grandiflora) populations have had mixed results (Paterson et al. 2005). Large-flowered fiddleneck appears to be more abundant in unburned than in burned plots. The reasons for this are unclear, although removal of the plant litter may result in increased seed predation. Additional monitoring work is needed to determine if prescribed burning has a use in restoration of this species.

Fire causes direct mortality of big tarplant (Blepharizonia plumosa) (Jones \& Stokes 2002; Paterson et al. 2005). In a seeming contradiction, big tarplant appears to be most abundant in areas that have been burned (Jones \& Stokes 2002), possibly because fire enhances seedling recruitment or reduces competition with annual grasses (Paterson et al. 2005). Soil moisture availability may also be an important factor influencing big tarplant population dynamics (Jones \& Stokes 2002), and the adverse effect of fire on soil moisture availability (Bennett et al. 2002; Snyman 2002, 2003) may be a reason that big tarplant seedlings in unburned areas are larger than those in burned areas (Paterson et al. 2005). Further study is needed to understand the relationship between fire and the ecology of big tarplant and to determine if fire may be needed as a tool for managing annual grasses where big tarplant occurs.

The effects of fire on diamond-petaled poppy (Eschscholzia rhombipetala) are unknown. The populations at Site 300 occur in unburned areas. Montalvo et al. (2002) found that smoke treatments enhanced germination of dormant California poppy (E. californica) seeds, and perhaps periodic fires would similarly benefit diamond-petaled poppy by producing a burst of recruitment. In addition, the abundance of plants appears to be negatively associated with high amounts of thatch (Paterson et al. 2005), suggesting that fire might have a positive effect on recruitment.

Fire may have little long-term effect on round-leaved filaree (California macrophyllum), as summer and autumn burns occur after the plants have senesced and dropped seeds (Gillespie and Allen 2004). Fire may cause a short-term decrease in seedling recruitment but may also result in a short- 
term increase in seed production (Gillespie and Allen 2004). The species appears to perform better in native grassland than with nonnative annual grasses (Gillespie and Allen 2004), so management measures to enhance native grasslands may also enhance round-leaved filaree. Five of the six populations at Site 300 occur in areas that have been unburned for more than 10 years (Paterson et al. 2005). Four of the populations occur along graded fire trails (Jones \& Stokes 2002; Paterson et al. 2005). Additional monitoring work is needed to determine if prescribed burning has a use in restoration of this species.

Gypsum-loving larkspur (Delphinium recurvatum) occurs on north-facing slopes at Site 300, generally associated with native perennial grasslands (Jones \& Stokes 2002). Because gypsumloving larkspur is a late-spring-blooming plant, fires occurring in May or June may have an adverse effect on seed and fruit production, although the plants themselves are perennial and are likely to survive fires. In the absence of fire, buildup of thatch may inhibit reproduction (Carlsen et al. 2001).

Three other species-California androsace (Androsace elongata subsp. acuta), stinkbells (Fritillaria agrestis), and hogwallow starfish (Hesperevax caulescens) - all bloom in early spring and would be unlikely to be affected by burns. The plants bloom and set seed before most fires occur, and the low vegetation cover where the plants occur would support only a low-intensity fire that would be unlikely to destroy the seed bank.

\section{Special-Status Wildlife}

Fire is unlikely to have substantial effects on special-status wildlife species occurring at Site 300 . Most species are able to avoid burns by fleeing to burrows or to unburned areas. Fire may create areas of low cover, improving prey visibility for raptors and insect-eating birds.

American badger (Taxidea taxus) occurs throughout Site 300 (Clark et al. 2003). Badgers are able to escape fire by remaining in their burrows or by fleeing to unburned areas. Because fires would not be expected to alter the number of small mammals in Site 300 grasslands, there would not be a change in the badger prey base.

Coastal sage scrub in the southwest quarter of the site is potential habitat for Alameda whipsnake (Masticophis lateralis euryxanthus). California whipsnakes (M. lateralis, subspecies not definitively determined) are present in this habitat, utilizing grasslands in the vicinity of the coastal sage scrub (Swaim Biological Consulting 2002). This habitat is not subjected to controlled burns. Although coastal sage scrub can recover from single fire events, repeated fires may covert coastal sage scrub to grassland (Keeley 2002).

Coast horned lizard (Phrynosoma coronatum) occurs throughout Site 300, including areas subject to controlled burns (Swaim Biological Consulting 2002). Fire could result in direct mortality of coast horned lizards, but they could escape fire by remaining in burrows or moving to areas of low vegetation cover. Frequent fires could have an adverse effect on coast horned lizard by reducing the abundance of harvester ants that are the primary prey for the species.

California red-legged frogs (Rana draytonii) occur in wetlands in the canyons at Site 300 (Hattem et al. 2003), including sites in or adjacent to areas subject to burns. Burns are unlikely to directly affect California red-legged frogs at Site 300 because they inhabit wetlands. However, fires could have indirect effects on California red-legged frogs. Frequent fires appear to increase soil erosion downgradient from burned areas (Woollett pers. comm.). Although no information is available on sedimentation effects on amphibians in lakes and ponds, sedimentation in streams adversely affects both abundance of adults and reproductive success (Pilliod et al. 2003). Burning could also 
adversely affect dispersal of California red-legged frogs by creating zones bare of vegetation, which would provide no cover and would have higher temperatures.

California tiger salamanders (Ambystoma californiense) breed in ponds in the northwest portion of Site 300 and in the southeast portion of the site along Corral Hollow Road (Hattem et al. 2003). Burns are unlikely to affect adult California tiger salamanders because dispersal events occur during winter rains, and adults spend the dry season in rodent burrows. Fires could affect juveniles during their dispersal from drying ponds into the adjacent grasslands, either causing direct mortality or creating zones bare of vegetation, which would provide no cover and would have higher temperatures. Soil erosion leading to sedimentation of the breeding ponds could also reduce reproductive success by burying eggs or adversely affecting larvae.

Western spadefoots (Spea hammondii) breed in ponds in the southeast portion of the site along Corral Hollow Road (Hattem et al. 2003). This is outside the area of controlled burns, so fires are unlikely to affect western spadefoot at Site 300.

Valley elderberry longhorn beetles (Desmoceras californicus dimorphus) occur in elderberry scrub in Gooseberry Canyon east of the 812 Complex and in the riparian zone along Corral Hollow Creek (Arnold 2002). These areas are outside the area of controlled burns and are usually not subject to burning. However, in 2005 a wildfire burned about half the vegetation on the Gooseberry Canyon site (Woollett pers. comm.). Although adult beetles could escape by flying to unburned areas, the fire would have killed larvae living in the stems of the elderberry plants. The stands of elderberry shrubs occurring outside Gooseberry Canyon are likely to be important as refuge for adult valley elderberry longhorn beetles and as potential breeding sites until the habitat in Gooseberry Canyon recovers. The riparian habitat along Corral Hollow Creek was not burned in the 2005 fire. Because of the mesic nature of riparian habitat, fires occur at a lower frequency and are generally of lower intensity than fires in uplands; and because the vegetation is green (except during extreme drought), fire may not spread far and patches of vegetation may remained unburned (Dwire and Kauffman 2003).

\section{Use of Fire as a Management Tool in Grassland Communities}

Prescribed burning has been promoted as a tool for managing native grasslands in California (Barry 1972; Menke 1992). Prescribed burning has historically been used to promote the condition of forage for livestock use, but it has evolved-as perspectives have shifted toward an ecological emphasis-into a tool to maintain or restore native perennial grasslands. The rationale for this management measure, which stems from the California bunchgrass prairie hypothesis, is summarized below (Menke 1992; Dyer and Rice 1997).

- Fire is a historical part of California ecosystems.

- The historical California grasslands were dominated by purple needlegrass, which appears to be adapted to fire.

- The original perennial grasslands have been replaced by introduced annual grasses, which appear to outcompete native grasses.

- Prescribed burning has been shown to reduce the cover and abundance of nonnative grasses.

- In view of the foregoing, prescribed burning is expected to lower the cover of nonnative annual grasses, reducing the level of competition with native perennial grasses, allowing the native perennial grasses to be restored to their original condition. 
Other potential benefits of using fire as a management tool have originated from range management practices for livestock. Fire may facilitate nutrient recycling in grasslands because standing litter is slow to decompose during the dry season (Vogl 1979). Buildup of litter may also create conditions more favorable to nonnative annual grasses than to native perennial grasses (Reynolds et al. 2001).

Despite the potential usefulness of fire as a grasslands management tool, as discussed above, the presumed benefits have not been confirmed experimentally for grasslands in California. The benefits of burning appear to be short term, and conditions return to pre-burn levels within 1 to a few years. Moreover, there is no benefit to native perennial grassland if native perennial grasses were never present on a site (Parsons and Stohlgren 1989; Keely 2001). Because most of the studies on the benefits of fire have been conducted on purple needlegrass, the applicability of the results for other perennial grass species is uncertain (D'Antonio et al. 2002).

Many factors appear to contribute to the paucity of definitive results in many of the studies, but perhaps these results would not have been surprising if the California bunchgrass prairie hypothesis was were not so deeply ingrained in the range management and ecological communities. Also, expectations based on a long history of fire management of perennial grasslands in temperate regions may be unrealistic for perennial grasslands occurring in arid areas (Bennett et al. 2002). The use of fire as a management tool in native perennial grasslands in California is still controversial and, therefore, experimental.

Although general use of fire as a landscape-wide tool may not be appropriate, use of fire as a tool for managing specific problems may still be appropriate. Prescribed burning is often recommended as a way to manage invasive species (Keeley 2001). The effect of fire is species-specific, so that while it may be useful for targeting specific exotics such as Medusa-head (Taeniatherum caput-medusae) (Pollak \& Kan 1998), yellow star-thistle (Centaurea solstitialis) (DiTomaso et al. 1999), or barb goatgrass (Aegilops triuncialis) (DiTomaso et al. 2001), it may not have a beneficial effect on other species. Although these studies have resulted in at least short-term control of nonnatives, other studies have found that this benefit may be short-lived or that burning actually enhances invasion by nonnatives (Keeley 2006).

In addition, fire as a vegetation management tool appears to have more promise when used in conjunction with other management measures. Dyer and Rice (1997) found no benefit to native perennial grasses with burning alone, but found a positive effect when nonnatives were weeded from the study plots. Seabloom et al. (2003a) also found no benefit to native perennial grasses from burning unless other treatments, such as seeding, were also used. Moyes et al. (2005) found that burning and solarization (heating the soil using plastic solarization sheets) both reduced the available seeds of nonnatives, so that sown seeds of natives were able to establish.

\section{Effects of Ceasing Prescribed Fire Operations}

Predicting the effect of ceasing prescribed burns at Site 300 following its 50-year use as a vegetation management tool is made difficult by the lack of a definitive relationship between fire and the composition of California grassland communities. Although BioSystems (1986) suggested that annual burns were responsible for maintaining grasslands dominated by native perennial grasslands at Site 300, other stands of pine bluegrass grassland in the interior South Coast Ranges do not appear to be subject to frequent burning (R. Preston, pers. obs.). No data are available on the distribution and composition of perennial grasslands on Site 300 prior to the start of prescribed fire operations, and except for the vegetation mapping conducted in 1986 and 2001, no sampling or 
monitoring of the perennial grassland vegetation has been done. Therefore, the extent of pine bluegrass grasslands at Site 300 prior to the start of controlled burning is unknown. Consequently, the actual effects of controlled burns on pine bluegrass stands-and whether these effects are beneficial-remains somewhat speculative.

The presumption that prescribed burns have benefitted native perennial grasslands at Site 300 may be grounded on the California bunchgrass prairie hypothesis, one tenet of which is that nonnative annual grasslands have replaced the original native perennial grasslands. A corollary of that hypothesis is that fire can be used as a tool to remove the nonnative grasses and allow restoration of the native perennial grasses. However, fire is a natural component of California ecosystems, and because the flora has evolved with periodic fires, burning should not be expected to have substantial effects, either beneficial or adverse, on the grassland community (Heady 1972; Vogl 1979).

Fire does not appear to have a substantial adverse effect on pine bluegrass; at least it has less effect than it has on other bunchgrass species, such as needlegrass species (Wright and Klemmedson 1965). At Site 300, pine bluegrass enters dormancy in early spring, well before the nonnative annual grasses (Carlsen et al. 2000), reducing its vulnerability to late-spring controlled burns. As noted above, a few studies have found burning to have positive beneficial short-term effects on native perennial grasses, but most studies have not been able to demonstrate that fire has any long-term effects-either beneficial or adverse-on native grasslands, with respect to nonnative annual grasses. On the other hand, fire does appear to have a role in maintaining the equilibrium between grasslands and scrub communities. Coastal sage scrub invades grassland in areas where fires have been suppressed, but this may be less of an issue on dry sites, such as Site 300 (Keeley 2002).

There is also little evidence to support the prediction that ceasing controlled burns would result in a decline in pine bluegrass grassland at Site 300. Competition from annuals may negatively affect the growth and reproduction of purple needlegrass (Dyer and Rive 1997; Hamilton et al. 1999), but other studies have shown that native perennial grasses, including pine bluegrass, can compete successfully with nonnative annual grasses, especially under mesic conditions (Biswell 1956; Hamilton et al. 2002; Seabloom et al. 2003b; Corbin and D'Antonio 2004; Monaco et al. 2005). Pine bluegrass grasslands are preferentially located on north-facing slopes at Site 300 (BioSystems 1986), and pine bluegrass appears to have a strong preference for north-facing slopes (Lulow et al. 2007; Harrison 1999; R. Preston pers. obs.), which are cooler and more mesic than other slope aspects in California. The habitat may give pine bluegrass a competitive advantage during drought years (Biswell 1956). Because pine bluegrass is a perennial, it begins growing immediately after the first autumn rains (Biswell 1956; Carlsen et al. 2000) and can tap into water deep in the soil, unlike annual grasses that must germinate and establish a root system before vegetative growth can occur and that rely on subsequent rainfall to maintain that growth.

Whether or not burning has been responsible for the abundance of pine bluegrass grassland at Site 300 , there are theoretical reasons to predict that the pine bluegrass grasslands at Site 300 would persist in the absence of controlled burns. Seabloom et al. (2003b) suggested that California grassland communities exist in a series of multiple stable equilibria, in which the current state of the grasslands is a result of past conditions and will remain stable in the absence of other factors. Several studies have noted the long-term persistence of both perennial grasslands and annual grasslands in the absence of grazing and other disturbances (White 1967; Stromberg and Griffin 1996; Harrison 1999; Jackson and Bartolome 2002; Hamilton et al. 2002). Jackson and Bartolome (2002) viewed California grasslands as a non-equilibrium community, predicting that the composition of the California grassland community changes as a result of abiotic factors, such as 
disturbance, rainfall patterns, or nutrient availability, rather than moving to a specific equilibrium condition determined by biotic factors, such as grazing levels or competitive interactions.

Recent results from rare plant restoration and monitoring activities at Site 300 have a bearing on predicting the effect of ceasing prescribed burns at Site 300. In sample plots established to study large-flowered fiddleneck that are, the density of pine bluegrass has also been monitored (Carlsen et al. 2003). These plots are subject to varied levels of burning, ranging from no burns to annual burns. After 10 years of monitoring, the density of pine bluegrass in plots burned annually increased significantly from the starting conditions, whereas the density of pine bluegrass in unburned plots decreased significantly from the starting conditions (Carlsen pers. comm.). These results are preliminary, because the test plots may not replicate the environmental conditions of the natural pine bluegrass stands, and the causative factors (e.g., competition with nonnative annual grasses, changes in soil chemistry, a combination of factors) for the difference between the treatments have not been established. Therefore, these results are not conclusive evidence that prescribed burns have been responsible for the abundance of perennial grasslands at Site 300, but they do raise a concern that, in the absence of prescribed burns, perennial grasslands at Site 300 would decline.

Two alternative scenarios for the future of pine bluegrass grasslands at Site 300 are suggested by ecological theory and by the results of monitoring at the site. First, native perennial grasslands may have been promoted by annual controlled burning, establishing a new equilibrium represented by the current distribution and composition of the grasslands. Under this scenario, no change in the total area, species richness, or species diversity would be expected as a result of ceasing prescribed fire operations. Because this equilibrium is dependent on various abiotic factors, a change in these factors may alter those conditions. The death of some pine bluegrass clumps could create gaps that might be filled by annual grasses, which have a more rapid germination rate than pine bluegrass, giving them a competitive edge in getting established (Hardegree et al. 2010). On the other hand, drought or wildfires, which suppress annual grasses for a short time, may provide windows of opportunity for establishment of pine bluegrass. The equilibrium between annual and perennial grassland would be dynamic, and the boundaries of the annual and perennial grasslands would likely shift along the margins. In the absence of site- wide disturbance, such as cattle grazing, other long-term changes, such as climatic trends or nitrogen deposition from air pollution, would result in gradual, subtle shifts in the overall composition and cover.

A second scenario is that annual burns may have exerted strong negative selection on nonnative annual grasses (Carlsen pers. comm.); such selection may have overridden other factors affecting the makeup of the grassland vegetation. For example, nonnative annual grasses might have a competitive advantage over pine bluegrass in drier portions of Site 300. If annual burns suppressed nonnative annual grasses-for example, by depleting the seed bank or by reducing the amount of available soil nitrogen - the practice may have allowed expansion of native perennial grassland into those drier areas. Under this scenario, ceasing prescribed burns would restore the competitive edge to the nonnative annual grasses in the drier portions of the perennial grasslands, resulting in a relatively rapid expansion of annual grassland and a corresponding decrease in native perennial grassland. Based on the existence of other stands of pine bluegrass in the South Coast Ranges, some stands of pine bluegrass grassland would persist at Site 300, although the extent cannot be predicted. Whichever scenario may be correct, careful long-term monitoring would be needed to detect the changes in the native perennial grasslands at Site 300 and to determine appropriate management measures. 
One unknown in formulating these scenarios is the response of small mammals to the absence of controlled burns. If ceasing controlled burns results in higher amounts of litter and increased cover, then the number of small mammals may increase. If small mammals become more abundant, grazing and seed predation may result in lower plant species diversity (Stromberg and Griffin 1996). Consumption of seeds by small mammals has been found to have a strong negative effect on establishment of native perennial grasses, as has grazing by squirrels and rabbits (Orrock et al. 2009). Increased burrow construction by small mammals could also affect perennial grasslands by creating areas of disturbance subject to invasion by nonnative annuals, although it could also provide areas for establishment of perennial grasses (Hobbs and Mooney 1985; Peart 1989; Schiffman 1994; Stromberg and Griffin 1996; Fehmi and Bartolome 2002). If the effects of small mammals on grasslands differ between annual and perennial grasslands, then this effect will need to be factored into functional models of the grassland ecology.

\section{Recommendations}

\section{Alternatives to Prescribed Burning at Site $\mathbf{3 0 0}$}

Vogl (1979) suggested that because fire is an integral part of the ecology of California ecosystems, it cannot be replaced by other measures, such as mowing, grazing, or herbicide use. Nevertheless, various other management tools have been tried to maintain and restore native perennial grasslands. The most effective tools may be those that focus on management of small areas, accounting for stand-specific characteristics and history (Hamilton et al. 2002). Alternative techniques and their potential applicability for Site 300 are discussed below.

\section{Grazing}

Grazing has been proposed as a management tool for controlling nonnative annual grasses and enhancing native perennial grassland (Edwards 1992; Menke 1992). Edwards (1992) suggested that because native California grasslands evolved under a regime of grazing by large herbivores, these communities are tolerant of grazing and may even benefit from it. Early reviews of California grassland ecology found that grazing reduced the frequency and density of nonnative annual species (Talbot et al. 1939) and that, with the exclusion of grazing, native perennial grasslands declined (Biswell 1956). However, the few studies that have been conducted to evaluate the effectiveness of grazing as a management tool have had mixed results, and no clear relationship has been found between grazing and native grassland species (D'Antonio et al. 2002).

Few studies have found grazing to have benefits on native California grasses. Malmstrom et al. (2006) found that competition with nonnative annual grasses may make native perennial grasses more susceptible to viral infections, and grazing may ameliorate this effect. Dyer (2003) found that some life history stages of purple needlegrass may benefit from grazing. Other studies have found that native forbs and nonnative grass and forbs benefitted from grazing, but native perennial grasses and forbs were unaffected or adversely affected by grazing (Hayes and Holl 2003; Kimball and Schiffman 2003). Grazing has been found to reduce the cover of annual grasses, but this effect appears to be temporary (Talbot el al. 1939). Even though grazing may temporarily reduce the cover of nonnative grasses, grazing does not appear to affect the diversity of nonnative species (Stromberg and Griffin 1996; Harrison 1999). Other studies have found no benefits of grazing to perennial grasses (Dyer et al. 1996; Dyer and Rice 1997; Marty et al. 2005). 
More often, grazing has clear adverse effect on native grasslands. On productive soils, grazing may promote invasion by nonnatives and reduce the number of natives (Safford and Harrison 2001). If small mammals are abundant, livestock grazing may result in lower plant species diversity because the lack of litter facilitates seed predation (Stromberg and Griffin 1996). Dyer (2002) found that grazing reduced seed size in purple needlegrass, suggesting that it has an adverse effect on seedling recruitment. Grazing appeared to adversely affect pine bluegrass, which was entirely absent from grazed study plots (Kimball and Schiffman 2003). Although Biswell (1956) noted a decline in pine bluegrass stands when grazing had been excluded, Heady (1977) characterized pine bluegrass as one of the few native perennial grasses capable of persisting without grazing. Even grazing by native large herbivores, such as tule elk, may have adverse effects on native perennial grasses similar to those of domestic livestock (Johnson and Cushman 2007). Accordingly, grazing is not recommended as a vegetation management tool for Site 300 .

\section{Seeding}

Seeding has shown some promise for restoring native grasslands. Lulow et al. (2007) had success planting native perennial grasses on sites where a seed bank of native grasses was absent. Success varied among the species used and by slope aspect; for example, pine bluegrass established at seven times greater cover on north-facing slopes than on south-facing slopes at the same planting density. Orrock et al. (2009) found that seeding of perennial grasses helped offset seed predation by small mammals. Even with high predation levels, doubling the amount of seed sown doubled the number of plants established. Seabloom et al. (2003a) found that seeding increased the number of native forbs in grasslands even with high densities of nonnatives. Seeding large-flowered fiddleneck has had mixed success (Paterson et al. 2005). Seed stocks can be produced successfully in cultivation, but seeding has been more successful at some sites than at others, perhaps because of seed predation. Seeding might be a useful management tool at Site 300, but it would be expensive, would require facilities for raising the seed stock, and would be limited to certain key species.

\section{Hand Weeding}

Dyer and Rice $(1997,1999)$ found that native grasses on plots where nonnatives had been removed by hand weeding had higher survival rates, were larger, and produced more flowering culms and, presumably, more seeds. Buisson et al. $(2006,2008)$ found that weeding increased survival rates and plant size among native grass transplants. Gillespie and Allen (2004) found that manual weeding greatly increased seed production in round-leaved filaree. Manual weeding might be useful as a management tool but would be costly and labor intensive. It likely would be most useful for establishing or restoring small areas of particular interest, such as locations with diamond-petaled poppy.

\section{Solarization}

Moyes et al. (2005) found solarization to be effective for eliminating the seed bank in grasslands dominated by nonnatives and allowing for the seeding of native species. Solarization consists of cultivating the ground to remove the above-ground litter and smooth the soil surface, watering the area to be treated, and then covering the area with plastic solarization sheets. When properly applied, solarization raises the soil temperature high enough to kill seedlings and seeds in the topsoil. The long-term effectiveness of this method has not yet been studied. Like hand weeding, this might be a useful tool for small areas of focused interest. 


\section{Topsoil Removal}

Buisson et al. $(2006,2008)$ found that topsoil removal increased survival rates and plant size among native grass transplants. This technique may have adverse effects on the native seed bank, soil microorganisms, and soil nutrients, and is only recommended for small, highly degraded sites.

\section{Recommended Management Practices}

Studies on California grassland management practices have not been able to demonstrate that burning and grazing have a clear benefit to the natural communities, and landscape-level management of California grasslands may be unnecessary. Hamilton et al. (2002) suggested that a better approach may be to manage individual stands, accounting for stand-specific characteristics and history. Recent studies have shown that, once established, native perennials appear to persist despite the presence of nonnatives, so there is no reason to expect, a priori, that native perennial grasslands at Site 300 will decline in the absence of fire. Accordingly, the recommended approach for managing native grasslands and other habitats at Site 300 is to monitor the plant and animal communities for adverse changes and apply management measures specific to those changes. The following management practices are recommended for carrying out this approach.

\section{Monitor Native Perennial Grasslands}

The purpose of monitoring native perennial grasslands at Site 300 is twofold. The first reason is to identify changes in species composition, distribution, and cover and to identify the factors responsible for those changes. If vegetation changes are observed, do they signal the presence of competitive interactions, are they a response to annual weather fluctuations, or might they reflect a consequence of climate change? Second, very little information has been collected on the pine bluegrass grassland community, and data obtained from Site 300 would be applicable to and valuable for the conservation and management of pine bluegrass grassland at a statewide level, not just at the site. Long-term monitoring is needed, as the species composition of California grasslands would be expected to vary annually with weather patterns, and such annual variations can obscure long-term changes (Jackson and Bartolome 2002).

\section{Inventory and Map Invasive Species}

Nonnative species such as the annual grasses that dominate the annual grasslands at Site 300 are ubiquitous and not invasive, and efforts to control or remove them would be futile. However, other invasive nonnative species have the potential to alter the habitats at Site 300, such as the exotic plant species listed in the California Invasive Plant Inventory (Cal-IPC 2006), and introduced wildlife such as bullfrogs (Rana catesbeiana), which have can adversely affect California tiger salamanders and California red-legged frogs. Infestations of these species at Site 300 should be targeted for eradication, using appropriate control measures.

\section{Rehabilitate Fire Trails}

If ceasing prescription burning at Site 300 includes abandonment of some of the fire trails, then these fire trails should be rehabilitated. Fire trails and dirt roads are a major route for invasion by invasive plant species, both because vehicles transport seeds and because the bare soil conditions are conducive to the establishment of invasive nonnative species (Merriam et al. 2006). For example, stinkweed (Dittrichia graveolens), a recently introduced exotic species that was collected at 
Site 300 in 1997 (Jones \& Stokes 2002), colonizes areas as a roadside weed, and then invades the adjacent grasslands (R. Preston, pers. obs.). It should be determined whether stinkweed has spread along fire trails at Site 300. Rehabilitation of the fire trails should take into account the adjacent vegetation; i.e., attempting to restore native perennial grasses at locations where the adjacent grasslands are dominated by nonnative annuals may be unproductive. The relationship between fire trails and populations of round-leaved filaree and big tarweed also must be determined so that rehabilitation of fire trails at the location of the populations does not adversely affect those species.

\section{Collect Experimental Data}

Much information has been collected on the effects of nonnative grasses, fire, and grazing on the ecology of purple needlegrass. Comparable data are lacking for pine bluegrass in California. Experimental protocols carried out for purple needlegrass should also be applied to stands of pine bluegrass at Site 300. The results of these studies would address such issues as whether burning favors pine bluegrass over nonnative annual grasses.

\section{Use Integrated Management Tools}

An integrated approach that uses prescribed burning and other methods of removing exotics in conjunction with seeding, planting, weeding, or solarization should be developed and implemented (Keeley 2001; Moyes et al. 2005). Although some of these tools are costly and labor intensive, their use is appropriate for management of smaller areas. These tools should be used for restoring areas infested with exotics, for rehabilitating fire trails and other disturbed areas, and for managing populations of special-status species. The efficacy of these methods should also be tested experimentally to confirm that they are useful in pine bluegrass grasslands.

\section{Recommended Study Approach}

As mentioned early in this document, it is recommended that a study approach be developed and implemented to collect information on the ecological changes over time in burned areas as well as those areas where burning activities are discontinued. These studies should address both flora and fauna at both the species and habitat scale.

\section{Monitoring Program}

To be able to detect changes that may occur over time in the controlled burn areas, a monitoring program is needed that (1) establishes baselines for the study areas; (2) collects quantitative data that allows statistical comparisons between sites and years, and (3) collects data for enough variables that a model of ecological processes can be constructed. Questions that the monitoring should address are listed below.

- What are the current native perennial grassland associations at Site 300, and do they correspond to the plant communities that BioSystems identified in 1986?

- Are there stands of native perennial grassland in unburned areas, and how do they differ from stands in burned areas?

- Does plant species richness and cover in native perennial grasslands change following cessation of controlled burns? 
- Does the composition of the vertebrate community differ between native perennial grasslands and nonnative annual grassland or among native perennial grassland associations?

- Does vertebrate species diversity and abundance change follow cessation of annual burns?

- Is there an effect of roads and fire trails on native perennial grasslands?

Monitoring should employ protocols that are standard and that provide useful information to the ecological and conservation communities as well as to resource managers at Site 300. The California Native Plant Society Relevé Protocol (California Native Plant Society 2007) is a standard vegetation classification protocol that has been used extensively to develop the current Manual of California Vegetation (Sawyer et al. 2009). Under this protocol, homogeneous stands are identified on the basis of a visual assessment of species composition and physical parameters (slope, aspect, soils), and then plots in each stand are sampled to identify the plant species, determine the cover of each species, and record other environmental information. The size and number of plots needed is determined during the initial sampling phase. Plot sizes typically range from 10 to 400 square meters, depending on species richness. Cover estimates are done visually to facilitate a rapid assessment of many stands. The plot locations should be mapped using a GPS data recorder to allow repeated sampling during subsequent years.

If changes that could affect wildlife use occur in the perennial grasslands, these changes would predominantly affect the small mammals and reptiles that forage and nest in the grasslands. Sampling for these wildlife species would include establishing traplines associated with the vegetation plots in accordance with the standard protocol for each group of species. Sampling efforts may need to be fairly extensive to ensure sample sizes large enough that statistical inferences can be drawn from the data.

The null hypothesis for testing and evaluating the effect of ceasing prescribed fire operations is that there will be no change in the total area, species richness, or species diversity of native perennial grasslands in the absence of prescribed burns. If changes in the native grassland parameters are detected, then further analysis of the environmental information collected may allow creation of a model or models, which can in turn be used to generate more specific hypotheses. The models will also help identify management measures that should be implemented.

\section{Experimental Approaches}

If the results of monitoring indicate that changes are occurring in the native perennial grasslands, the cause or causes of the change may not be readily apparent. Without knowing the cause of change, the choice of management measures may not be apparent. If possible, an experimental approach should be used to determine which ecological processes may be responsible for the changes-for example, interspecies competition or the interaction between plant species and small mammal herbivores and granivores. These experiments could parallel studies conducted on purple needlegrass and purple needlegrass grassland, such as those performed at Jepson Prairie (Dyer et al. 1996; Dyer and Rice 1997, 1999; Dyer 2002, 2003) or by Marty et al. (2005). 


\section{References}

Allen, E. B. 2006. Effects of Fire on Chemical, Physical, and Biotic Properties of Soil. Pages 33-40 in DiTomaso, J. M. and D. W. Johnson (eds.), The Use of Fire as a Tool for Controlling Invasive Plants. Cal-IPC Publication 2006-01. Berkeley, CA: California Invasive Plant Council..

Arnold, R. A. 2002. Report on the Threatened Valley Elderberry Longhorn Beetle and its Elderberry Food Plant at the Lawrence Livermore National Laboratory-Site 300. September. Pleasant Hill, CA. Prepared for Lawrence Livermore National Laboratory, Livermore, CA.

Barry, W. J. 1972. The Central Valley Prairie. Sacramento, CA: California Department of Parks and Recreation.

Bartolome, J. W., W. J. Barry, T. Griggs, and P. Hopkinson. 2007. Valley Grasslands. Pages 367-393 in M. G. Barbour, T. Keeler-Wolf, and A. A. Schoenherr (eds.), Terrestrial Vegetation of California, third edition. Berkeley, CA: University of California Press.

Bartolome, J. W., J. S. Fehmi, R. D. Jackson, and B. Allen-Diaz. 2004. Response of a Native Perennial Grass Stand to Disturbance in California's Coast Range Grassland. Restoration Ecology 12(2):279-289.

Bartolome, J. W., and B. Gemmill. 1981. The Ecological Status of Stipa pulchra (Poaceae) in California. Madroño 28(3):172-184.

Beck, A. M., and R. J. Vogel. 1972. The Effects of Spring Burning on Rodent Populations in a Brush Prairie Savanna. Journal of Mammalogy 53(2):336-346.

Bennett, L. T., T. S. Judd, and M. A. Adams. 2002. Growth and Nutrient Content of Perennial Grasslands Following Burning in Semi-Arid, Sub-Tropical Australia. Plant Ecology 164:185-199.

BioSystems Analysis, Inc. 1986. Vegetation of Site 300, Lawrence Livermore National Laboratory, San Joaquin County, California. July. Santa Cruz, CA. Prepared for: Science Applications International, Inc., Pleasanton, CA.

Biswell, H. H. 1956. Ecology of California Grasslands. Journal of Range Management. 9(1):19-24.

Bock, C. E., and J. H. Bock. 1978. Response of Birds, Small Mammals, and Vegetation to Burning Sacaton Grasslands in Southeastern Arizona. Journal of Range Management 31(4):296-300.

Buisson, E., K. D. Holl, S. Anderson, E. Corcket, G. F. Hayes, F. Torre, A. Peteers, and T. Dutoit. 2006. Effect of Seed Source, Topsoil Removal, and Plant Neighbor Removal on Restoring California Coastal Prairies. Restoration Ecology 14(4):569-577.

Buisson, E., S. Anderson,K. D. Holl, E. Corcket, G. F. Hayes, A. Peteers, and T. Dutoit. 2008. Reintroduction of Nassella pulchra to California Coastal Grasslands: Effects of Topsoil Removal, Plant Neighbour Removal and Grazing. Applied Vegetation Science 11:195-204.

Burcham, L. T. 1957. California Range Land: an Historico-Ecological Study of the Range Resource of California. Sacramento, CA: California Division of Forestry, Department of Natural Resources, State of California.

Cal-IPC. 2006. California Invasive Plant Inventory. Cal-IPC Publication 2006-02. Berkeley, CA: California Invasive Plant Council. Available: <www.cal-ipc.org>. 
California Department of Fish and Game. 2007. List of California Vegetation Alliances. October. Sacramento, CA: Biogeographic Data Branch, Vegetation Classification and Mapping Program.

California Native Plant Society. 2007. California Native Plant Society relevé protocol. August 23, 2007. Available: http://www.cnps.org/cnps/vegetation/pdf/cnps_releve_protocol_20070823.pdf>.

California Natural Diversity Database. 2010. RareFind, Version 3.1.0 (July 3, 2010 update). California Department of Fish and Game. Sacramento, CA.

Carlsen, T. M., E. K. Espeland, and A. H. Smith. 2001. Rare Plant Restoration and Monitoring at Lawrence Livermore National Laboratory Site 300: Project Progress Report Fiscal Year 2000 (October 1999-September 2000). UCRL-AR-142408. Livermore, CA: Lawrence Livermore National Laboratory, University of California.

Carlsen, T. M., J. W. Menke, and B. M. Pavlik. 2000. Reducing Competitive Suppression of a Rare Annual Forb by Restoring Native California Perennial Grasslands. Restoration Ecology 8(1):1829.

Carlsen, T., L. E. Paterson, and E. Espelund. 2003. Rare Plant Restoration and Monitoring at Lawrence Livermore National Laboratory, Site 300: Project Progress Report Fiscal Year 2002 (October 2001September 2002). UCRL-AR-142408-02. November. Livermore, CA: Lawrence Livermore National Laboratory, University of California.

Chance, R. L. 1986. The Effect of Fall Burning on Small Mammals in Blue Mounds State Park, Luverne, Minnesota. Pages 157-159 in G.K. Clambey and R.H. Pemble (eds.), Proceedings of the Ninth North American Prairie Conference. Moorhead, MN: Tri-College University Center for Environmental Studies.

Clark, B. K., and D. W. Kaufman. 1990. Short-Term Responses of Small Mammals to Experimental Fire in Tallgrass Prairie. Canadian Journal of Zoology 68:2450-2454.

Clark, H. O., Jr., D. A. Smith, B. L. Cypher, and P. L. Kelly. 2003. Mesocarnivore Surveys on Lawrence Livermore National Laboratory Site 300, Alameda and San Joaquin Counties, California. February. Fresno, CA. Prepared for Lawrence Livermore national Laboratory, Livermore, CA.

Clements, F. E. 1920. Plant Indicators: the Relation of Plant Communities to Process and Practice. Washington, DC: Carnegie Institution of Washington.

-——. 1934. The Relict Method in Dynamic Ecology. Journal of Ecology. 22:39-68.

Clements, F. E., and V. E. Shelford. 1939. Bio-Ecology. New York, NY: John Wiley and Sons.

Cook, S. F. 1959. The Effects of Fire on a Population of Small Rodents. Ecology 40(1):102-108.

Corbin, J. D., and C. M. D’Antonio. 2004. Competition between Native Perennial and Exotic Annual Grasses: Implications for an Historical Invasion. Ecology 85(5):1273-1283.

Crowner, A. W., and G. W. Barrett. 1979. Effects of Fire on the Small Mammal Component of an Experimental Grassland Community. Journal of Mammalogy 60(4):803-813.

D’Antonio, C., S. Bainbridge, C. Kennedy, J. Bartolome, and S. Reynolds. 2002. Ecology and Restoration of California Grasslands with Special Emphasis on the Influence of Fire and Grazing on Native Grassland Species. Unpublished report. Berkeley, CA: University of California. 
DiTomaso, J. M., K. L. Heise, G. B. Kyser, A. M. Merenlender, and R. J. Keiffer. 2001. Carefully Timed Burning Can Control Barb Goatgrass. California Agriculture 55(6): 47-53.

DiTomaso, J. M., G. B. Kyser, and M. S. Hastings. 1999. Prescribed Burning for Control of Yellow Starthistle (Centaurea solstitialis) and Enhanced Native Plant Diversity. Weed Science 47:233242.

Dwire, K. A., and J. B. Kauffman. 2003. Fire and Riparian Ecosystems in Landscapes of the Western USA. Forest Ecology and Management 178:61-74.

Dyer, A. R. 2002. Burning and Grazing Management in a California Grassland: Effect on Bunchgrass Seed Viability. Restoration Ecology 10(1):107-111.

_-_. 2003. Burning and Grazing Management in a California Grassland: Growth, Mortality, and Recruitment of Nassella pulchra. Restoration Ecology 11(3):291-296.

Dyer, A. R., H. C. Fossum, and J. W. Menke. 1996. Emergence and Survival of Nassella pulchra in a California Grassland. Madroño 43(2):316-333.

Dyer, A. R., and K. J. Rice. 1997. Intraspecific and Diffuse Competition: the Response of Nassella pulchra in a California Grassland. Ecological Applications 7(2):484-492.

Edwards, S. W. 1992. Observations on the Prehistory and Ecology of Grazing in California. Fremontia 20(1):3-11.

Erwin, W. J., and R. H. Stasiak. 1979. Vertebrate Mortality during Burning of a Reestablished Prairie in Nebraska. American Midland Naturalist 101(1):247-249.

Espeland, E. K., T. M. Carlsen, and D. MacQueen. 2005. Fire and Dynamics of Granivory on a California Grassland Forb. Biodiversity and Conservation 14:267-280.

Fehmi, J. S., and J. W. Bartolome. 2002. Species Richness and California Voles in an Annual and a Perennial Grassland. Western North American Naturalist 62(1):73-81.

Geluso, K. N., G. D. Schroder, and T. B. Bragg. 1986. Fire-Avoidance Behavior of Meadow Voles (Microtus pennsylvanicus). American Midland Naturalist 116(1):202-205.

Gillespie, I. G., and E. B. Allen. 2004. Fire and Competition in a Southern California Grassland: Impacts on the Rare Forb Erodium macrophyllum. Journal of Applied Ecology 41:643-652.

Gonzalez, S., and L. Ghermandi. 2008. Postfire Seedbank Dynamics in Semiarid Grasslands. Plant Ecology 199: 175-185.

Hamilton, J. G. 1997. Changing Perceptions of Pre-European Grasslands in California. Madroño 44(4):311-333.

Hamilton, J. G., J. R. Griffin, and M. R. Stromberg. 2002. Long-Term Population Dynamics of Native Nassella (Poaceae) Bunchgrasses in Central California. Madroño 49(4):274-284.

Hamilton, J. G., C. Holzapfel, and B. E. Mahall. 1999. Coexistence and Interference between a Native Perennial Grass and Non-Native Annual Grasses in California. Oecologia 121:518-526.

Hardegree, S. P., C. A. Moffet, B. A. Roundy, T. A. Jones, S. J. Novak, P. E. Clark, F. B. Pierson, and G. N. Flerchinger. 2010. A Comparison of Cumulative-Germination Response of Cheatgrass (Bromus 
tectorum L.) and Five Perennial Bunchgrass Species to Simulated Field-Temperature Regimes. Environmental and Experimental Botany 69:320-327.

Harrison, S. 1999. Native and Alien Species Diversity at the Local and Regional Scales in a Grazed California Grassland. Oecologia 121:99-106.

Harrison, S., B. D. Inouye, and H. D. Safford. 2003. Ecological Heterogeneity in the Effects of Grazing and Fire on Grassland Diversity. Conservation Biology 17(3):837-845.

Hatch, D., J. W. Bartolome, and D. Hillyard. 1991. Testing a Management Strategy for Restoration of California Native Grasslands. Pages 343-349 in: Yosemite Centennial Symposium Proceedings: Natural Areas and Yosemite, Prospects for the Future, a Global Issues Symposium Joining the 17th Annual Natural Areas Conference with the Yosemite Centennial Celebration, October 13-20, 1990, Davis California. Denver, CO: National Park Service, Branch of Publications and Graphic Design, Denver Service Center.

Hatch, D. A., J. W. Bartolome, J. F. Fehmi, and D. S. Hillyard. 1999. Effects of Burning and Grazing on a Coastal California Grassland. Restoration Ecology 7(4):376-381.

Hattem, M. V., L. Paterson, and J. Woollett. 2003. The Current and Historical Distribution of Special Status Amphibians at the Livermore Site and Site 300. Livermore, CA: Lawrence Livermore National Security.

Hayes, G. F., and K. D. Holl. 2003. Cattle Grazing Impacts on Annual Forbs and Vegetation Composition of Mesic Grasslands in California. Conservation Biology 17(6):1694-1702.

Heady, H. F. 1972. Burning and the Grasslands in California. Proceedings of the Annual Tall Timbers Fire Ecology Conference 12:97-107.

_-_. 1977. Valley grassland. Pages 491-514 in M. G. Barbour and J. Major (eds.), Terrestrial Vegetation of California. New York, NY: John Wiley and Sons.

Hervey, D. F. 1949. Reaction of a California Annual-Plant Community to Fire. Journal of Range Management 2(3):116-121.

Hickman, J. C. (ed.). 1993. The Jepson Manual: Higher Plants of California. Berkeley, CA: University of California Press.

Hoagstrom, C. W., T. A. Schetter, and L. L. Tumino. 1992. Effect of a Prescribed Burn on the Small Mammals of an Old Field in the Prairie Peninsula Area of Ohio.Pages 55-57 in D. C. Hartnett (ed.), Proceedings of the $14^{\text {th }}$ Annual North American Prairie Conference. Manhattan, KS: Kansas State University.

Hobbs, R. J., and Mooney, H. A. 1985. Community and Population Dynamics of Serpentine Grassland Annuals in Relation to Gopher Disturbance. Oecologia 67:342-51.

Holland, R. F. 1986. Preliminary Descriptions of the Terrestrial Natural Communities of California. Sacramento, CA: California Department of Fish and Game,

Holstien, G. 2001. Pre-Agricultural Grassland in Central California. Madroño 48(4):254-264.

Jackson, R. D., and J. W. Bartolome. 2002. A State-Transition Approach to Understanding Nonequilibrium Plant Community Dynamics in Californian Grasslands. Plant Ecology 162:49-65. 
Jepson, W. L. 1925. A Manual of the Flowering Plants of California. Associated Students Store, Berkeley, CA: University of California.

Johnson, B. E., and J. H. Cushman. 2007. Influence of a Large Herbivore Reintroduction on Plant Invasions and Community Composition in a California Grassland. Conservation Biology 21(2):515-526.

Jones \& Stokes. 2002. Special-Status Plant Species Surveys and Vegetation Mapping at Lawrence Livermore Laboratory. September. (J\&S 02-136.) Sacramento, CA. Prepared for Lawrence Livermore National laboratory, Livermore, CA.

- - 2003. 2002 Small Mammal Inventory at Lawrence Livermore National Laboratory Site 300. September. (J\&S 02-205.). Sacramento, CA. Prepared for University of California, Lawrence Livermore National Laboratory, Livermore, CA.

Kaufman, D. W., E. J. Finck, and G. A. Kaufman. 1990. Small Mammals and Grassland Fire. Pages 4680 in S. L. Collins and L. L. Wallace (eds.), Fire in North American Tallgrass Prairies. Norman, OK: University of Oklahoma Press.

Kaufman, D. W., G. A. Kaufman, and E. J. Finck. 1983. Effects of Fire on Rodents in Tallgrass Prairie of the Flint Hills Region of Eastern Kansas. Prairie Naturalist 15:49-56.

- - 1989. Rodents and Shrews in Ungrazed Tallgrass Prairie Manipulated by Fire. Pages 173177 in T. B. Bragg and J. Stubbendieck (eds.), Proceedings of the Eleventh North American Prairie Conference. Lincoln, NE: University of Nebraska Press.

Kaufman, G. A., D. W. Kaufman, and E. J. Finck. 1988. Influence of Fire and Topography on Habitat Selection by Peromyscus maniculatus and Reithrodontomys megalotis in Ungrazed Tallgrass Prairie. Journal of Mammalogy 69(2):342-352.

Keeley, J.E. 2001. Fire and Invasive Species in Mediterranean-Climate Ecosystems of California. Pages 81-94 in K. E. M. Galley and T. P. Wilson (eds.), Proceedings of the Invasive Species Workshop: the Role of Fire in the Control and Spread of Invasive Species. Fire Conference 2000: the First National Congress on Fire Ecology, Prevention, and Management. Miscellaneous Publication No. 11. Tallahassee, FL: Tall Timbers Research Station.

- - 2002. Native American Impacts on Fire Regimes of the California Coastal Ranges. Journal of Biogeography 29:303-320.

- - 2006. Fire Management Impacts on Invasive Plants in the Western United States. Conservation Biology 20(2):375-384.

Kellogg, E. A. 1985a. Variation and Names in the Poa secunda complex. Journal of Range Management 38(6):516-521.

- - 1985b. A Biosystematic Study of the Poa secunda Complex. Journal of the Arnold Arboretum 66: 201-242.

Kimball, S., and P. M. Schiffman. 2003. Differing Effects of Cattle Grazing on Native and Alien Plants. Conservation Biology 17(6):1681-1693.

Klinger, R.C., and I. Messer. 2001. The Interaction of Prescribed Burning and Site Characteristics on the Diversity and Composition of a Grassland Community on Santa Cruz Island, California. Pages 
66-80 in: K. E. M. Galley and T. P. Wilson (eds.), Proceedings of the Invasive Species Workshop: the Role of Fire in the Control and Spread of Invasive Species. Fire Conference 2000: the First National Congress on Fire Ecology, Prevention, and Management. Miscellaneous Publication No. 11. Tallahassee, FL: Tall Timbers Research Station.

Lulow, M.E., T. P. Young, J. L. Wirka and J. H. Anderson. 2007. Variation in the Initial Success of Seeded Native Bunchgrasses in the Rangeland Foothills of Yolo County, California. Ecological Restoration 25(1):20-28.

Malmstrom, C. M., C. J. Stoner, S. Brandenburg, and l. A. Newton. 2006. Virus Infection and Grazing Exert Counteracting Influences on Survivorship of Native Bunchgrass Seedlings Competing with Invasive Exotics. Journal of Ecology 94:264-275.

Marty, J. T., S. K. Collinge, and K. J. Rice. 2005. Responses of a Remnant California Native Bunchgrass Population to Grazing, Burning and Climatic Variation. Plant Ecology 181:101-112.

Menke, J. W. 1992. Grazing and Fire Management for Native Perennial Grass Restoration in California Grasslands. Fremontia 20(2):22-25.

Merriam, K. E., J. E. Keeley, and J. L. Meyers. 2006. Fuel Breaks Affect Nonnative Species Abundance in Californian Plant Communities. Ecological Applications 16(2):515-527.

Mills, A. J., and M. V. Fey. 2004. Frequent Fires Intensify Soil Crusting: Physicochemical Feedback in the Pedoderm of Long-Term Burn Experiments in South Africa. Geoderma 121: 45-64.

Minnich, R. A. 2008. California's Fading Wildflowers: Lost Legacy and Biological Invasions. Berkeley, CA: University of California Press.

Monaco, T. A., S. B. Monsen, B. N. Smith, and L. D. Hansen. 2005. Temperature-Dependent Physiology of Poa secunda, a Cool Season Grass Native to the Great Basin, United States. Russian Journal of Plant Physiology 52(5):653-658.

Montalvo, A. M., L. J. Feist-Alvey, and C. E. Koehler. 2002. The Effect of Fire and Cold Treatments on Seed Germination of Annual and Perennial Populations of Eschscholzia californica (Papaverceae) in southern California. Madroño 207-227.

Moyes, A. B., M. S. Witter, and J. A. Gamon. 2005. Restoration of Native Perennials in a California Annual Grassland after Prescribed Spring Burning and Solarization. Restoration Ecology 13(4):659-666.

Murphy, D. D., and P. R. Ehrlich. 1989. Conservation Biology of California's Remnant Native Grasslands. Pages 201-211 in L. F. Huenneke and H. Mooney (eds.), Grassland Structure and Function: California Annual Grassland. Dordrecht, the Netherlands: Kluwer Academic Publishers.

Munz, P. A., and D. D. Keck. 1949. California Plant Communities. Aliso2: 87-105.

Neary, D. G., C. C. Klopatek, L. B. DeBano, and P. F. Folliott. 1999. Fire Effects on Belowground Sustainability: a Review and Synthesis. Forest Ecology and Management 122:51-71.

Ojima, D. S., D. S. Schimel, W. J. Parton, and C. E. Owensby. 1994. Long- and Short-Term Effects of Fire on Nitrogen Cycling in Tallgrass Prairie. Biogeochemistry 24:67-84. 
Orrock, J. L., M. S. Witter, and O. J. Reichman. 2009. Native Consumers and Seed Limitation Constrain the Restoration of a Native Perennial Grass in Exotic Habitats. Restoration Ecology 17(1):148157.

Panzer, R., and M. Schwartz. 2000. Effects of Management Burning on Prairie Insect Species Richness within a System of Small, Highly Fragmented Reserves. Biological Conservation. 96:363-369.

Parsons, D. J., and T. J. Stohlgren. 1989. Effects of Varying Fire Regimes on Annual Grasslands in the Southern Sierra Nevada of California. Madroño 36(3):154-168.

Paterson, L., E. Espelund, and T. Carlsen. 2005. Rare Plant Restoration and Monitoring at Lawrence Livermore National Laboratory, Site 300: Project Progress Report, Fiscal Years 2003 \& 2004 (October 2002-October 2004). September. Livermore, CA: Lawrence Livermore National Laboratory, University of California.

Peart, D. R. 1989. Species Interactions in a Successional Grassland. III. Effects of Canopy Gaps, Gopher Mounds and Grazing on Colonization. Journal of Ecology 77:267-289.

Picone, L. I., G. Quaglia, F. O. Garcia, and P. Laterra. 2003. Biological and Chemical Response of a Grassland Soil to Burning. Journal of Range Management 56:291-297.

Pilliod, D. S., R. B. Bury, E. J. Hyde, C. A. Pearl, and P. S. Corn. 2003. Fire and Amphibians in North America. Forest Ecology and Management 178:163-181.

Pollak, O., and T. Kan. 1998. The Use of Prescribed Fire to Control Invasive Exotic Weeds at Jepson Prairie Preserve. Pages 241-249 in C.W. Witham, E.T. Bauder, D. Belk, W.R. Ferren Jr., and R. Ornduff (eds.), Ecology, Conservation, and Management of Vernal Pool Ecosystems-Proceedings from a 1996 Conference. Sacramento, CA: California Native Plant Society.

Reed, A. W., G. A. Kaufman, and D. W. Kaufman. 2004. Influence of Fire, Topography, and Consumer Abundance on Seed Predation in Tallgrass Prairie. Canadian Journal of Zoology 82:1459-1467.

- - 2005. Rodent Seed Predation and GUDs: Effect of Burning and Topography. Canadian Journal of Zoology 83(10):1279-1285.

Reynolds, S. A., J. D. Corbin, and C. M. D'Antonio. 2001. The Effects of Litter and Temperature on the Germination of Native and Exotic Grasses in a Coastal California Grassland. Madroño 48(4):230235.

Safford, H. D., and S. P. Harrison. 2001. Grazing and Substrate Interact to Affect Native vs. Exotic Diversity in Roadside Grasslands. Ecological Applications 11(4):1112-1122.

Sawyer, J. O., T. Keeler-Wolf, and J. E. Evens. 2009. A Manual of California Vegetation. $2^{\text {nd }}$ ed. Sacramento, CA: California Native Plant Society.

Schiffman, P. M. 1994. Promotion of Exotic Weed Establishment by Endangered Giant Kangaroo Rats (Dipodomys ingens) in a California Grassland. Biodiversity and Conservation 3:524-537.

- - - 2007. Species Composition at the Time of First European Settlement. Pages 52-56 in M. R. Stromberg, J. D. Corbin, and C. M. D'Antonio (eds.), California Grasslands: Ecology and Management. Berkeley, CA: University of California Press.

Schlising, R., G. Treber, and C. Warren. 1996. First-Year Response to Fire by the California Grassland Perennial, Dodecatheon clevelandii ssp. patulum (Primulaceae). Madroño 43(1):93-96. 
Schramm, P., and B. J. Willcutts. 1983. Habitat Selection of Small Mammals in Burned and Unburned Tallgrass Prairie. Pages 49-55 in R. Brewer (ed.), Proceeding of the Eight North American Prairie Conference. Kalamazoo, MI: Western Michigan University.

Seabloom, E. W., E. T. Borer, V. L. Boucher, R. S. Burton, K. L. Cottingham, L Goldwasser, W. K. Gram, B. E. Kendall, F. Micheli. 2003a. Competition, Seed Limitation, Disturbance, and Reestablishment of California Native Annual Forbs. Ecological Applications 13(3):575-592.

Seabloom, E. W., W. S. Harpole, O. J. Reichman, and D. Tilman. 2003b. Invasion, Competitive Dominance, and Resource Use by Exotic and Native California Grassland Species. Proceedings of the National Academy of Sciences USA 100(23):13384-13389.

Sharry, J. A. 2010. Site 300 Explosive Test Facility, Prescribed Burn/Smoke Management Plan. Livermore, CA: Lawrence Livermore National Laboratory.

Snyman, H. A. 2002. Fire and the Dynamics of a Semi-Arid Grassland: Influence on Soil Characteristics. African Journal of Range \& Forage Science 19:137-145.

- - - 2003. Short-Term Response of Rangeland Following an Unplanned Fire in Terms of Soil Characteristics in a Semi-Arid Climate of South Africa. Journal of Arid Environments 55:160-180.

Stromberg, M. R., and J. R. Griffin. 1996. Long-Term Patterns in Coastal California Grasslands in Relation to Cultivation, Gophers, and Grazing. Ecological Applications 6(4):1189-1211.

Swaim Biological Consulting. 2002. Results of Surveys for Special Status Reptiles at the Site 300 Facilities of Lawrence Livermore National Laboratory. October. Livermore, CA. Prepared for Lawrence Livermore National Laboratory, Livermore, CA.

Talbot, M. W., H. H. Biswell, and A. L. Hormay. 1939. Fluctuations in the Annual Vegetation of California. Ecology 20(3):394-402.

Twisselmann, E. C. 1967. A Flora of Kern County, California. Wasmann Journal of Biology 25:1-395.

Vogl, R. J. 1979. Some Basic Principles of Grassland Fire Management. Environmental Management 3(1):51-57.

Wester, L. 1981. Composition of Native Grasslands in the San Joaquin Valley, California. Madroño 28(4):231-241.

White K. L. 1967. Native Bunchgrass (Stipa pulchra) on Hasting Reservation, California. Ecology 48:949-955.

Wright, H. A., and J. O. Klemmedson. 1965. Effect of Fire on Bunchgrasses of the Sagebrush-Grass Region in Southern Idaho. Ecology 46(5):680-688.

\section{Personal Communications}

Carlsen, Tina. Plant Ecologist. Lawrence Livermore National Laboratory. September 13, 2010 comments on draft report submitted by email.

Preston, Robert. Various dates, 1990-2010- field notesfrom botanical surveys. 
Woollett, Jim. Wildlife Biologist. Lawrence Livermore National Laboratory. September 14, 2010email. 